Volume 16, Number 1, Juni 2019
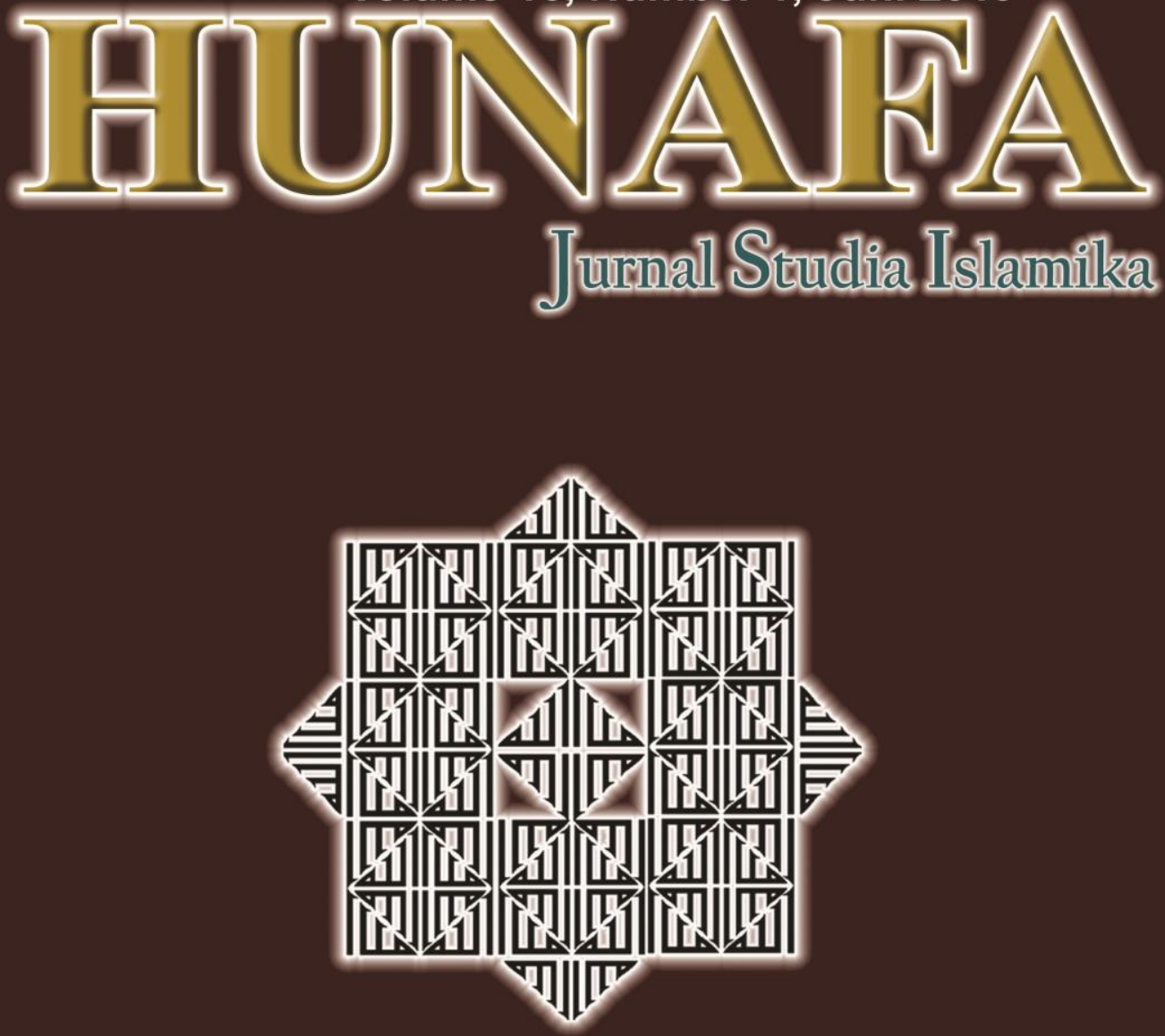

ALKHAIRAAT POLITICAL CHARISMA

Syamsuri

IRAN REVOLUTION, ECONOMIC STRUGGLE AND INDEPENDENCE UNDER PRESSURE Meirizon Alizar Ali

MARKETING PERFORMANCE DETERMINANT OF HALAL PRODUCTS IN INDONESIA Confirmatory Factor Analysis Approach Aan Nasrullah

State lnstitute for lstamis Studies (IAALN) Pallu central Sulawesi

\begin{tabular}{|c|c|c|c|c|c|}
\hline $\begin{array}{c}\text { HUNAFA } \\
\text { JSI }\end{array}$ & $\begin{array}{c}\text { Volume } \\
16\end{array}$ & $\begin{array}{c}\text { Number } \\
1\end{array}$ & $\begin{array}{c}\text { Page } \\
1-153\end{array}$ & $\begin{array}{c}\text { Palu } \\
\text { Juni } 2019\end{array}$ & $\begin{array}{c}\text { ISSN } \\
1411-125 X\end{array}$ \\
\hline
\end{tabular}




\section{HUNAFA}

Jurnal Studia Islamika

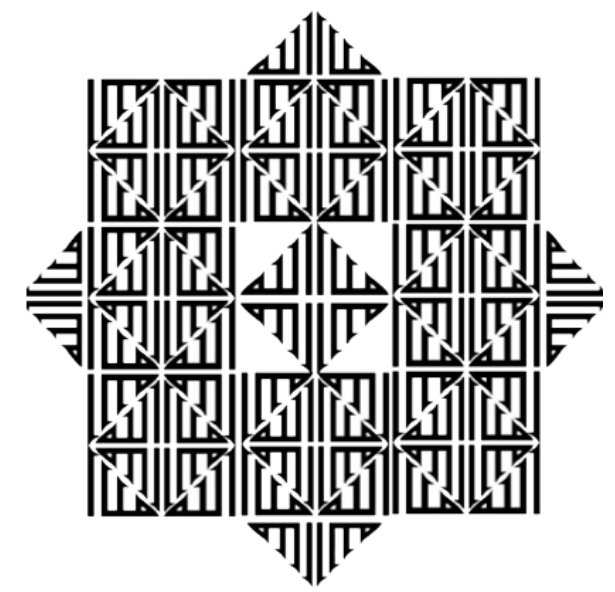

Published by:

State Islamic Institute (IAIN) Palu

Central Sulawesi 


\section{HUNAFA}

Jurnal Studia Islamika

HUNAFA: Jurnal Studia Islamika is an Islamic studies journal dedicated to publishing scholarly articles on all aspects of Islam and the Muslim peoples and religious studies. Available in print and online and published twice a year, the journal aims to become one of the leading platforms in Indonesia for new findings and discussions of all fields of Islamic studies. This journal invites scholars, researchers, and students to contribute the result of their studies and researches in the areas related to Islam and Muslim society which covers textual and fieldwork investigation with various perspectives of law, education, quranic studies, economiy, philosophy, mysticism, theology, sociology, and others.

\section{CAll rights reserved}

No part of this publication may be reproduced in any form without written permission from HUNAFA, to whom all requests to reproduce copyright material should be directed. HUNAFA grants authorization for individuals to photocopy copyright material for private research use. This authorization does not extend to any other kind of copying, by any means, in any form, and for any purposes other than private research.

\section{Open Acces Journal Information}

The journal provides immediate open access to its content on the principle that making research freely available to the public supports a greater global exchange of knowledge. The journal offers full access contents at http://jurnalhunafa.org.

\section{Printed Journal Subscription Information}

Institution Rp 100.000,00 /issue; Rp 1.100.000,00/year

Individual: Rp. 60.000,00/issue; Rp. 600.000,00/year

Outside Indonesia (individual or institution) \$60/month; \$600/year

For detail information of printed journal subscription, feel free to contact the journal manager at hunafajournal@gmail.com.

\section{Mailing Address}

HUNAFA: Jurnals Studia Islamika

Lembaga Penelitian dan Pengabdian Masyarakat (LP2M) IAIN Palu 
Jl. Diponegoro No. 23 Palu, Sulawesi Tengah 94221 Indonesia

Phone: +62-451-460798; Fax: +62-451-460165

E-mail: jurnalhunafa@yahoo.com; hunafajournal@gmail.com

Website: www.jurnalhunafa.org

HUNAFA

Jurnal Studia Islamika

\section{EDITOR-IN-CHIEF}

Nurdin, Institut Agama Islam Negeri Palu, Indonesia

\section{EDITORIAL BOARD}

Sagaf S. Pettalongi, Institut Agama Islam Negeri Palu, Indonesia

Rusli, Institut Agama Islam Negeri Palu, Indonesia

Tulus Suryanto, Universitas Islam Negeri Raden Intan Lampung, Indonesia

Ade Yeti Nuryantini, Universitas Islam Negeri Sunan Gunung Djati, Indonesia

Toto Suharto, Institut Agama Islam Negeri Sukoharjo, Indonesia

Reza Fahmi, Universitas Islam Negeri Imam Bonjol Padang, Indonesia

Mohamad Abdalla, University of South Australia, Australia

Cucuk Wawan Budiyanto, Universitas Sebelas Maret, Indonesia

Kevin W. Fogg, University of Oxford, United Kingdom

Al Makin, Universitas Islam Negeri Sunan Kalijaga Yogyakarta, Indonesia

Miftachul Huda, Universiti Teknologi Malaysia, Malaysia

Hendri Tanjung, Ibn Khaldun University Bogor, Indonesia

Muhammed Modassir Ali, Hamad bin Khalifa Universty, Qatar

Hamid Fahmi Zarkasyi, Universitas Darussalam Gontor, Indonesia 


\section{MANAGING EDITOR}

Mohammad Nur Ahsan, Institut Agama Islam Negeri Palu, Indonesia

\section{COVER DESIGN}

Lukman Latif 


\section{HUNAFA \\ Jurnal Studia Islamika}

\section{Contents}

Editorial

vi-vii

AL-KHAIRAAT POLITICAL KHARISMA

$1-18$

Syamsuri

BANGRENG AS A MEANS OF SPREADING ISLAM

Melyan Sofian, Cece Sobarna, Reiza D. Deinaputra, Deni Hermawan

FOREIGN LANGUAGE TEACHING AND INFORMATION COMMUNICATION TECHNOLOGY: IS THERE OPPORTUNITY FOR QURANIC LANGUAGE TEACHERS?

Nuril Mufidah, Abduganiy Abimbola Abdussalam, Aliy Abdulwahid Adebisi

IRAN REVOLUTION, ECONOMIC STRUGGLE AND INDEPENDENCE UNDER THE PRESSURE

Meirozon AlizarAli 
Umi Salamah

MAHRAM IMPLICATIONS IN WOMEN'S TRAVEL

$88-110$

Maulidah Tri Utami

MARKETING PERFORMANCE DETERMINANT

OF HALAL PRODUCTS IN INDONESIA:

Confirmatory Factor Analysis Approach

Aan Nasrullah

RELATIONS BETWEEN MOSQUE AND

$142-153$

SOCIAL HISTORY OF ISLAMIC EDUCATION

Anna Triayudha, Rateh Ninik Pramitasary, Hermansyah Akbar Anas, Choirul Mahfud 


\section{Editorial Preface}

Nurdin Nurdin, Institut Agama Islam Negeri (IAIN) Palu

This issue (Vol. 16 issues 1) of Hunafa: Jurnal Studia Islamika offers eight articles covering topics of Islamic studies. Various issues relating to Islamic studies are presented interestingly to contribute to the body of knowledge and practices. Academia and practitioners in Islamic studies may gain insight from reading these articles.

The first article is titled "Al-Khairaat Political Kharisma" by Syamsuri Syamsuri from Department of Dakwah, Faculty of Ushuluddin, Adab, and Dakwah, Institut Agama Islam Negeri Palu. This paper discusses the roles of Al-Khairaat in politics arena within local and national level. Several political parties have come to the Alkhairaat organization to recruit political cadres in the face of general election events.Alkahiraat's political charisma in the frame of political communication includes the participation, consolidation, and partnership of Alkhairaat politicians who spread in various political parties to win the election contestation.

The second article in the issue is titled "Bangreng as a Means of Spreading Islam" by Maylan Sofian, Cece Sobarna, Reiza D. Dienaputra, and Deni Hermawan from STKIP Sebelas April Sumedang. This paper describe Bangreng culture which was originally an example used by the Sumedang community as a medium to express gratitude for everything that Allah SWT gave to humans. But the function of art as a ritual began to shift into art as entertainment. This Bangreng art is an art that is very interesting to study because there are only a few different functions. This change does not change the name of the show. With this description, it needs to be isolated, that is, the community does not lose identity. The aim is that the public knows the function of the nation in the spread of Islam.

The third article is titled "Determinants of Halal Product Marketing Performance In Indonesia: Confirmatory Factor Analysis Approach" by Aan Nasrullah. This paper discussed the five variables that contribute to halal product marketing which are product competition, HR marketing performance, infrastructure, amount of distribution cost, and market competition.

The fourth article is titled "Foreign Language Teaching and Information Communication Technology: Is There Opportunity for Quranic Language Teachers?"by Nuril Mufidah, Abdulganiy Abimbola Abdussalam, Aliy Abdulwahid Adebisi from UIN Maulana Malik Ibrahim Malang and University of Ilorin, Ilorin, Nigeria. The article discuses the use of ICT in learning of Arabic. The subjects of the study were students of Arabic Language Education at UIN Maulana Malik Ibrahim Malang Indonesia 2018 academic year and students and Department of Arabic, Faculty of Arts University of Ilorin, Nigeria. The findings of the research are that ICT if adequately harnessed and utilized will go a long way in enhancing the quality of teaching of Arabic, as it was established to teaching other languages of the world.

The fifth article is by Meirizon Alizar Ali dari UIN Imam Bonjol. The article is titled "Iran Revolution, Economic Struggle and Independence under the Pressure" The article discusses 
Iran economy situation after experiencing various kinds of changes in economic policy and facing various kinds of situations Iran succeeded in developing the economy without changing the basics of Islamic shari'ah principles and revolution.

The sixth article is titled "Kaisa Method in Intelligence Multiple Perspective" by Umi Salamah from PGMI, STAI Ma'had 'Aly Al-Hikam, Malang. The article analyzed memorizing the Qur'an using the Kaisa method in the perspective of multiple intelligence. The Kaisa method is a way of memorizing the Qur'an which is oriented to memorization and understanding of the verses of the Qur'an along with their meanings through movements or kinesthetic which are adapted to the meaning of each verse so as to make it easy to understand and remember every verse of the Qur'an given.

The seventh article is titled "Mahram Implications in Women's Travel" by Maulidah Tri Utami from Faculty UshuluddinAdab and Humaniora, IAIN Salatiga. The article discusses mahram as well as a culture of the manner in which a woman is going out of her home or is drawn. From the various resources available this article determine when a woman can compete without mahram.that is how Islam respects and cares for a woman so much that it also notices when a woman is about to travel. Not just one woman, but all Muslim have a rule if a Muslim is to compete for a long time. So, when to reply a Muslim must meet or finish what he needs before taking a sauna.

The last article is titled "Relations Between Mosque And Social History of Islamic Education" by Choirul Mahfud Anna Triayudha, Rateh Ninik Pramitasary, and Hermansyah Akbar Anas from Institut Teknologi Sepuluh Nopember, Surabaya and Pascasarjana Universitas Muhammadiyah Sidoarjo. The article describe the early period of Islamic education, the Prophet provided exemplary by building and empowering mosques. The example of the Prophet continued with the Caliphs afterwards until the present era. The mosque was built by the Prophet from the Al Haram mosque located in Makkah, Quba Mosque located in Quba, Nabawi mosque located in Medina and so on. The role and function of the mosque at that time was as a place of prayer, a place of prayer, a place for discussion or deliberation, a meeting place to develop a war strategy and others related to the problems and needs of Muslims. From time to time, the role or function of the mosque has changed slightly. In essence, mosques are currently influencing the development of the social history of Islamic education in Indonesia.

I hope the articles presented in this issue add further empirical evidence to the growing body of research that examines various fields from Islam perspectives. The articles could trigger other research to study other field of study with Islam perspectives Islamic institutions in Indonesia.

Nurdin Nurdin

Editor-in-Chief

HUNAFA: Jurnal Studia Islamika

XVI, 1 


\title{
IRAN REVOLUTION, ECONOMIC STRUGGLE AND INDEPENDENCE UNDER THE PRESSURE
}

\author{
Meirizon Alizar Ali ${ }^{1}$ \\ ${ }^{1}$ UIN Imam Bonjol, Padang, meirison.a@gmail.com
}

\begin{abstract}
Iran is a country that has great potential to achieve progress because it has a strong and independent economy system. However, the American Embargo has stifled the Iranian economy, but with certain steps and natural gas resources that can be used as weapons, changes to laws that support investments that have received protests from conservatives continue. Will Iran succeed in realizing independence in the Industrial field? The author conducts discussions with qualitative methods and conducts literature studies to collect data and get it directly from official sources from the Iranian embassy in Jakarta. After experiencing various kinds of changes in economic policy and facing various kinds of situations Iran succeeded in developing the economy without changing the basics of Islamic shari'ah principles and revolution.
\end{abstract}

Keywords: Iranian Revolution, Economic Struggle and Independence, Pressure

\begin{abstract}
Abstrak. Iran adalah negara yang mempunyai potensi besar untuk meraih kemajuan karena mempunyai sistim perekoniman yang kuat dan indpenden. Akan tetapi Embargo Amerika telah membuat geliat ekonomi Iran terhenti, akan tetapi dengan langkah yang pasti dan sumber migas yang dapat dijadikan senjata, perubahan undang-undang yang mendukung investasi yang mendapatkan protes dari kaum konservatif tetap berjalan. Akankah Iran berhasil dalam mewujudkan kemandirian di bidang Industri? Penulis melakukan pembahasan dengan metode kualitatif dan melakukan studi pustaka untuk mengumpulkan data serta dan mendapatkannya langsung dari sumber resmi dari kedutaan Iran di Jakarta.Setelah mengalami berbagai macam perubahan kebijakan perekonomian dan menghadapi berbagai macam situasi Iran berhasil mengembangkan perekonomian tanpa merubah dasar-dasar prinsip syari'at Islam dan revolusi.
\end{abstract}

Kata Kunci: Revolusi Iran, Perjuangan dan Kemandirian Ekonomi, Tekanan 
DOI: $10.24239 /$ jsi.v16i1.530.56-79

\section{Introduction}

In the beginning, the Islamic revolution in Iran had not yet been set up as a standard economic system, considering that the Iran revolution had been going on for more than 30 years which arose with an independent and free economy from the Western economy. To restore Iran's economic condition before the Revolution, it took a long time due to various factors. But development after development took place in Iran which was different from Iran in the 80s. Iran is an Islamic country that continues to face threats and pressure, especially from the United States. The normalization of relations with the West and the United States of course will make Iran's economic direction will change from the goal of a revolution that wants economic freedom and independence with all forms of policy. Syi'ar Iran is maintaining its economy from imperialist forces and globalization. Syi'ar was then extinguished because in order to progress an economy, Iran had to join the world economy. Will changing the Iranian law succeed in developing the economy?, does Iran have other weapons to increase the economy and negotiate with various countries for industrial development? Will the unilateral impact of America's withdrawal from the nuclear agreement destroy the Iranian economy in total?

\section{Method}

This is a qualitative research, by conducting literature studies and information in the form of data from embassy sources that provide an explanation of the Iranian economy. By comparing the sources of changes in economic concepts embraced by Iran and their implications for the economic development of Iran which has been under Western pressure for more than 40 years. Information obtained is also from official sources from the Iranian Embassy orally.

\section{Discussion}


After the death of Khomeini, Iran began to adjust its economic practices to world economic policies. The ideology of the Iranian economy turned into a pragmatic policy. Beginning political elites fight to make policy changes towards democracy. The Iranian government system has a flexible policy of foreign pressure, and the state also intervenes with social groups to play a role in renewing economic policy. This is done so that there is no dominance of small elite groups in determining policy and as a manifestation of ideas given by the community towards transparent systems and economic practices. In the Islamic Republic of Iran now there is no single actor who can determine the politics and policies of the country like the time of the Iran Shah. Now there are several contemporary Iranian political institutions. But still the ability of representatives and political elites within it is very weak to be able to color Iran's politics in contrast. There are also institutions that are effective in influencing Iranian economic policies, such as the National Law Guard Council, Revolutionary Guard and others. ${ }^{1}$

The supreme leader in the Islamic Republic of Iran, plays an important role in determining the direction of public policy and can oversee its implementation directly, as well as the highest leaders of the armed forces, Ulama and experts who are in the preservation committee. Elements of the law keeper and the owner of the government's benefit also consisted of ulama, supreme court chief, minister of communication and information technology, and commanders of the armed forces. $^{2}$

\section{Post-Revolutionary Economic Independence}

The revolution began in 1979 based on Iran's economic freedom which was an interaction with Western and Capitalist actions which had dominated the territory of Iran before. Revolution speeches mix with Marxism and Religion or Islamization of Marxist thought. Because the Iranian revolutionary group is

${ }^{1}$ Fatimah Shamadi Tayarat Siyasah Fi Iran (Wadi Nabat: Markaz Dirasat al-Arabia, 2012),26

${ }^{2}$ Hasan Hakimian The Economic of Iran, Dilemmas of an Islamic State (London: IB Tauris Publisher, 2010), 114 
divided into two, namely the Islamic and Secular groups, from an economic point of view it is considered as a radical left line. When the law is re-arranged, all aspects of the strategic economy are controlled by the state. Such as large and small industries, foreign trade, mining, banking, energy, dams, irrigation, information, domestic and foreign transportation. The law also recognizes and maintains private property. The protection is stated in article 46,47 , that the personal deacons as the owner of the investment and all legal activities and he has the right to reap the proceeds of his business which are maintained and protected by the state. ${ }^{3}$

The Iranian Revolution was initially opposed to capitalism, the points stated in the Law constituted resistance to the foreign monopoly on the domestic economy. This is stated in article 43 which reads "institutions related to trade, industry, agriculture, mining and services are prohibited from monopolizing and obtaining special rights unless they get approval from parliament". In fact, there is very little foreign investment in Iran, because the United States has imposed sanctions since November 1979 when the United States embassy was held in Tehran. Coupled with the unstable investment situation and environment due to prolonged wars both in Iran and in neighboring countries such as Afghanistan, Iraq and Syria. Economic freedom in Iran has not yet reached self-sufficiency in various fields. the percentage of imports continues to increase compared to Gross Domestic Product and the Iranian economy still adheres to the mining sector, especially oil and gas. Beginning the Iranian economic elite glancing at the market economy. In 1988 after the Iraq-Iran war, the Iranian government began focusing on the export-import trade in non-oil commodities. ${ }^{4}$

\section{Redefining the Purpose of the Revolution}

Economic power is political power, economics is considered as a part of secondary material in a history course, or economics is an independent science

${ }^{3}$ Parvin Ali Zadeh, Hasan Hakimian, Iran and The Global Economic Petro Populism Islam and Economic Sanction (New York:Routledge, 2014),89

${ }^{4}$ M.Cass Richard Economic Santion and US Diplomacy(London: Palgrave, 2005), 167 
that can be used to interpret history. Although liberal theory demands the existence of two separate systems that support each other, namely political science and economics. Both of these sciences apply in reality and this also applies to Iran. During the Iraq and Iran wars, it was important for Iran to safeguard its natural resources and play in foreign policy as an independent player. After the war there were various economic problems faced by the Islamic Republic of Iran. The problem requires a solution, because in the early period it was seen that the main economic activity experienced inaction. After the war, parties related to the benefit of trade began asking for facilities and to carry out their activities. But economic freedom is not ignored, only economic freedom is redefined in an effort not to ignore it in the time of Hasyemi Rafsanjani. ${ }^{5}$

Traders and economists are urging the government to reduce government control over the economy and restart economic relations with several friendly countries. This requires the establishment of a new agenda to go through the second development period in the political, social and economic development of the country after the revolution. Formed two camps of economic politics, trade development and trade politics. After Rafsanjani was appointed as the president, he began to move to improve the economy. Trade relations with the outside world began to be established but did not forget the independence of the economy. The Rafsanjani government faces problems, falling GDP, dependence on oil production, unemployment, weak balance of payments, uneven growth in regions and provinces and rapid population growth. Coupled with low management and administrative experience, that was what was faced at the beginning of his reign in $1989^{6}$. Start companies get facilities, such as cooperation with foreign insurance in various projects and development that are considered potential businesses in rebuilding infrastructure. National oil companies are permitted to enter into contracts and agreements with suitable foreign companies. However, it is feared that the influence of culture will spread to the

${ }^{5}$ Ghorbani, Mansour The Economic Geology of Iran (London: Springer 2013),19

${ }^{6}$ Amuzeger, Jahangir Iran,s Economic Under the Islamic Republic (London: I.B Tauris, 2016),22 
people of entrepreneurs and the community associated with this foreign nation. ${ }^{7}$ Foreign insurers also play a role in building dams, nuclear reactors, heavy and light industries, such as the weapons, automotive and textile industries. This new economic policy has come under fire from representatives of the people and politicians, especially from the field of society and culture. The rise of Ronald Reagen and the collapse of the Soviets in the 90s made economic liberalism dominate the world including the Islamic Republic of Iran. The condition of Iran politically and economically began to improve after the Iraq and Kuwait war in 1990, oil prices rose. However, foreign investment still did not show significant growth in the early 1990s. When Rafsanjani was reappointed as president in 1993, the economy experienced severe degradation. The five-year steps planned are far from the desired results. Imports increased from $24 \%$ to $38 \%$, payments and trade balance as much as a deficit of 9.5 Trillion Dollars. The government received strong criticism that made it no longer run on a free economic system, so the role of Iran's financial system was lost. Rafsanjani said that the second Repelita was focused on debt repayment, but the government still allowed to get foreign capital in various development projects. Economic watchdogs including the World Bank and IMF said "after the end of the Iraq war and the death of Khomeini will make Iran return to normal as before the revolution. ${ }^{8}$ Because Iran has used a fragmatic policy, but in reality Iran is heading towards economic openness which has not yet produced the desired results. Hasyemi Rafsanjani's election as President of Iran in 1989 was accompanied by an increase in oil prices. This has created a conducive situation for realizing economic freedom. Special sectors and foreign investment will play an important role in Iran's economy. However, the World Bank in 1994 predicted that Iran's economic independence would not be possible in the near future and in the long run of the US embargo, the future of Iram's economy remained uncertain. ${ }^{9}$ Iran's economic independence faces many

\footnotetext{
${ }^{7}$ Keddie, Niki, Iran: Religion, Politics, and Society (New York: Frank Cass and Company Limited, 2005),171

${ }^{8}$ Ibrahim Gharaybah at-Tsaurah Islamiyah wa Iqtishadiyah, Shira' an-Nakhb Haula Istiqlal Haula Istqlal al-Iqtishadiyah al-Irani (Jeddah:Syubr, 2013), 145

${ }^{9}$ Ibid., 22
} 
and varied challenges, such as the legacy of the revolution and different perceptions about that inheritance. At the beginning of the Hasyemi Rafsanjani government there was a shadow of the emergence of a straight step for economic liberation. A conducive situation in the early 90s, continuous policy changes to support the economy. The Majlis Garda law, members of the council join the economic benefit forum. However, in 1994 there were tensions between conservative opposition groups in parliament because of pragmative government policies. There is a complex compromise about the legacy of the revolution among the warring and competing groups in government.

\section{Actions for Reformation}

Karl Marx said "human beings create their own history, but the history they create is not in accordance with their wishes or in conditions that benefit them. They even create challenges that they must face, a condition inherited from their predecessors. The culture of a nation that has passed is like a nightmare that remains in the minds of living creatures. Khatami explained when he was appointed as the President of the Islamic Republic of Iran, that he could not predict Iranian politics. This was commented on by the New York Time newspaper "coalition government carried out by Khatami vulnerable to disputes and difficulties. Because this coalition consists of the old left wing and its supporters who tend to centralize the economy and the Bazar traders from Tehran who have backgrounds related to the old Iranian trading system. Its members also consist of technocrats who want greater openness and freedom for the private sector. ${ }^{10}$ Most people abstained from political arena. Starting from 1997 the group which had influence in determining political economic policy in Iran which is in the system of government has changed to be pragmatic. Some groups that had adopted centralistic ideas turned into reformists. The reformers are between positions, centralized groups and traders who tend to be liberal in parliament. The American attitude which continues to pressure Iran is increasingly making the possibility to get foreign investment even more difficult,

\footnotetext{
${ }^{10}$ Ibid., 36
} 
even though the investment law is prepared in such a way as to support Iran's economy. Under the auspices of the majority of groups with centralized thighs under Iran's murshid Ali Khamenai. After Ahmadi Najad was appointed as the fourth presidential repelita, it was declared that increased foreign freedom in investing. The South African company is licensed to operate in managing mobile networks in Iran. This was protested by conservatives, they debated the aims of the revolution and foreign services. The appointment of Ahmadi Nejad as president is an attempt to combine the spirit of revolution, economic openness and economic globalization. Iran's response to attitudes changing and openness is still experiencing uncertainty. Is Iran going to make peace with the United States to open the door to free trade, investment, especially in the oil and gas industry which is the locomotive of the country's growth. But the dominance of conservatives in Iran does not want that. Because the aim of the revolution is to avoid incoming foreign capital and investment. Because foreign capital and investment are very detrimental and are part of Western exploitation of Muslim countries. The new strategy is designed to penetrate the world market by avoiding the destruction that will befall Iran caused by the threat of unwanted Western imperialism. The purpose of the revolution must be maintained, but the goal is adjusted to the existing reality in accordance with the urgent needs of the Islamic Republic of Iran. This need is felt through experience in politics, economics and foreign trade policy. ${ }^{11}$

All agreed that the Western exploitation of Iran must end, this was the step from the Revolution towards mutual benefit. However, the government does not yet have a detailed and practical strategy to do this, because this is a very heavy task that must be faced together. Iran's political economy adheres to the ideological views formed by the party of the Islamic Republic of Iran after the revolution. ${ }^{12}$ The state is responsible for all sectors and forms of factors of

\footnotetext{
${ }^{11}$ Hooshang Amirahmadi, Revolution and Economic Transition: The Iranian Experience(New York: State University of New York Press, 1990), 126

${ }^{12}$ Harold , Scott Waren and Nader, Alireza, China and Iran: Economic, Political, and Military Relations(California: Rand Corporation, 2012), 166
} 
production and limits special ownership, the prohibition of foreign investment, realizing self-sufficiency in all fields. Proponents of this ideology oppose the transfer of strategic economic sectors to the private sector. ${ }^{13}$ The economic outlook is closer to socialism, although it is different in several ways. ${ }^{14}$

Musawi, as prime minister at the beginning of the revolution, tried to implement a socialist government system, alleviating poverty, preserving and defending the cultural values of Islam and the Revolution. However, war, embargo and economic sanctions and others have made the country's income in the oil and gas sector very small. This has limited the government's performance in implementing its plans for economic development. ${ }^{15}$ Bisran argued differently, he said "the emergence of Khatami in government was the beginning of general political reform. Khatami has designed the third decade of the revolution as an era of reform based on political development, transparency, openness in foreign policy and democratic institutions. ${ }^{16}$ The left wing group gave a new perspective on reforms in economic politics, which originally defended the country by banning privatization of support for the market economy and breaking the country's economic blockade. ${ }^{17}$ Central government share the labyrinth, the elected president is the second power in the center of power, murshid al-a'la is the first power. The power structure has four rounds, the Mullahs and Ulemas, highranking state officials, mayors, technocrats, leaders of the armed forces, security forces, militias, mass media and opposition. Iranian politics is regulated by several institutions such as murysid al-a'la, presidents, parliaments, ministerial assemblies, such as experts' assemblies, majors of the benefit of the government, Majlis Garda UU. In addition there are also informal institutions that have huge capital. This institution organizes many giant activities and projects that have hundreds of trillions.

\footnotetext{
${ }^{13}$ Ibrahim Gharaybah at-Tsaurah Islamiyah wa Iqtishadiyah, Shira' an-Nakhb Haula Istiqlal Haula Istqlal al-Iqtishadiyah al-Irani (Jeddah:Syubr, 2013), 45-46

${ }^{14}$ Ibid. 86

${ }^{15}$ Ibid. 47

${ }^{16}$ Ibid. 55.

${ }^{17}$ Ibid.161
} 
Economic openness in the era of globalization, reform or vice versa, Iran has been able to build a strong economic foundation. The advanced carpet industry, automotive, heavy equipment such as excavators, tractors, mining equipment, nonwovens, petrochemicals. These industries are outside the oil and gas sector. Iran's GDP in 2011 has reached 824 billion dollars. Of course Iran still has many diverse economic problems which causes are not far from US embargo politics. ${ }^{18}$

On April 26, 2019 Iranian President Hasan Rohani mentioned that Iran did not face economic difficulties after 40 years of the Revolution passed far from political interpretations and expressions, in fact Iranian society faces economic difficulties, high inflation, unemployment, low income, sometimes poverty and low exchange rates. Iran has been trying to free its economy from the grip of a Superpower like the United States. It maintains a balance of surplus and expenditure, trade balance of payments. Iran avoids debt with foreign currencies, especially when implementing weapons industry projects that have achieved success in several sectors. The largest surplus depends on the volume of oil sales and oil prices on the world market. Iran does not export many other commodities except oil and its associated products. Iran has historically been a country laden with trade, but after Iran was embargoed and closed to trade after the Revolution. Iran accounts for $13 \%$ of gross national income, while the world's average national income is $21 \%$. While Iran's exports reached $37 \%$, received by countries such as China and Turkey. Another trade channel that is also limited is Iraq until Iraqi oil production has recovered. While the financial condition of Iraq after the war is better than Iran. However, Iran remains in a stable condition. Since revolution, the average investment has reached 19\% / year. After the nuclear agreement between Iran and several countries, inflation began to decline by $10 \%$. However, after the United States withdrew from the agreement, inflation in Iran soared, inflation in September 2018 had reached 5.5\%, the annual cumulative rate reached $80 \%$. The unemployment rate according to official figures has reached

\footnotetext{
${ }^{18}$ Ahmad Saif, Iqtishad Siyasi Iran Mu'ashir (Teheran: H\&S, 2018), 159
} 
$12.5 \%$ while the unofficial figures say $18 \%$ and $30 \%$ of this figure consists of productive age groups. The Ministry of Education announced that 20 thousand doctoral degree students have received diplomas, but only 4000 up to 5000 of them are getting jobs in accordance with their education. Some of these doctors have become taxi drivers. This is not much different from other regions in the Middle East. In 2007-2017 there was an increase in population in Arab countries by $25 \%$, in Egypt $25.6 \%$, Turkey 15. 5\%, Israel 20\% while Iran reached $12.5 \%$. Iran is an old country before its time, before this country became rich because it has a lot of potential. Soil fertility in Iran increased by $2 \%$. This development began in the Khamenai era in 1989, the development of the oil industry, not to mention renewed, and lack of investment and capital. So the groups that had supported the revolution and war that had a big role in forming rulling class thought disappeared in 2009. Opposition groups are increasing due to economic, social and political situations which are difficult to predict due to world market conditions and US pressure which all exert negative impact on Iran. ${ }^{19}$

\section{Distinctions of the Iranian Economy ${ }^{20}$}

1. Iran's economy is the 18 th best economy in the world

2. Iran's economy continues to grow in the financial crisis

3. Educated and professional young people

4. Rich in natural resources

5. Strong and broad economic infrastructure

6. Privileges of diverse natural and mining resources

7. Diversity of economic factors rich in hydrocarbon, oil, and gas resources

8. The fourth largest oil producing country in the world

9. The world's second biggest natural gas producer

10.The fifth largest natural tourism industry in the world

${ }^{19}$ Jawad Hasan, "Problem Invest in Iran," Middle East Economic Journal, 26, no.1 (2014).pp.61-5.

${ }^{20}$ Ibrahim Gharaybah at-Tsaurah Islamiyah wa Iqtishadiyah, Shira' an-Nakhb Haula Istiqlal Haula Istqlal al-Iqtishadiyah al-Irani (Jeddah:Syubr, 2013), 61-63 
11.The largest industrial volume in the Middle East and Africa region

12.The fourth largest producer of Cobalt and Zinch in the world

13.The world's largest producer of aluminum, manganese and metals

14.The world's fourth producer of biodiversity in the food sector

15.Economic Renewal with the Repelita Program

16.20 billion dollars of private sector investment and foreign investment in the oil and gas industry

17.Reducing unemployment levels from $13 \%$ to $7 \%$ in real terms by creating millions of new jobs in all provinces every year.

18.Improvement of the country's security guarantee system

19.Expanding international relations

20.GDP multiplies

21.Privatization on a broad scale

$22.80 \%$ State ownership and assets are transferred to the private sector

$23.40 \%$ of the assets are transferred in shares

$24.40 \%$ of the privatization was transformed on the Tehran stock market

25.The government owns $20 \%$ of the total assets

26.The volume of state assets is worth 120 billion dollars

27.In the last 5 years (starting from 2014) state assets have been transferred valued at 63 billion dollars

28.After privatization, the government shares will experience a decrease in local production by $80-40 \%$.

\section{Privileges of the Investment Law ${ }^{21}$}

1. Guarantee for withdrawal of shares and loss suffered from technical errors (Article 9)

2. Guaranteed reimbursement of investment termination due to laws or state decisions (Articles 17 and 26).

${ }^{21}$ Fawaz bin Hamdi Fawaz Hukuk wa Tashilat li Istitsmar fi Iran (Qatar: Arabia Li Dirasat, 2016), 215 
3. Guaranteed purchases of goods and services and production services that are part of foreign investment undergo price changes adjusted by the government (Article 11)

\section{Rights and Facilities ${ }^{22}$}

1. Foreign investors have the same rights as local investors (Investment Law, Article 8)

2. Freedom of capital transfers and profits generated by domestic investment in currency and goods (articles 13-18)

3. $100 \%$ foreign investment permitted in investment in development and industrial projects (Investment Act article 4)

4. Foreign investment agreements in various sectors of production and industry, agriculture, cargo, relations, services, insurance, water, electricity, gas and energy

5. Possible resolution of investment problems in international courts (Article 19)

6. Opportunity to own land in the name of the company (registered in Iran) in a joint investment (Investment Act article 34)

7. Providing facilities, visas, residence permits for three years in Iran for foreign investors, managers, experts with their families and given the possibility to extend the residence permit. (Investment Law, Articles 20 and 35).

8. Applications are processed within a maximum grace period of 45 days (Investment Law, article 6)

9. Choose the method of investment in the plan taken, Foreign Direct Investment (FDI) or through the contract process by means of the BOT, with community participation in the investment (Investment Law, article 3).

10.Give permits to local residents who invest in foreign capital and provide simplicity and facilities for foreign investors (Investment Act article 1)

Introduction of Investment Opportunities in $\operatorname{Iran}^{23}$

\footnotetext{
${ }^{22}$ Ibid., 218

${ }^{23}$ Behzad Yaghmaian Social Change in Iran: An Eyewitness Account of Dissent, Defiance, and New Movements for Rights (New York: State Univrsity of New York, 2002), 216
} 
1. Providing facilities through internet sites for investment enthusiasts in Iran with the WWW.iio.ir site, including:

2. Get investment opportunities in Iran in various fields of economy.

3. Get translation and interpretation of law in various world discussions.

4. Present statistical data on foreign investment electronically in opportunities offered to potential investors and can be done online.

5. Participation in international conferences attended by owners of capital and companies.

\section{Investment Conditions and Feasibility in Iran}

1. Responsible Parties: investment institutions, technical and economic assistance in Iran

2. Legal Framework: Foreign investment law and related matters

\section{Foreign Investment Service Center}

Provides information and interpretation desired by foreign investors about: ${ }^{24}$

- Hold meetings and discussions with potential investors

- Sending information through print and electronic media

- Direct contact through communication media

\section{Components of Iran's Economy}

The Islamic Republic of Iran has a strong economic foundation, military and security integration, and a clear and established economic strategy. ${ }^{25}$ Not only that, there is also the support of the community who maintain the system and regime to remain upright. Iran occupies the second position in the economy after Saudi Arabia, in the Middle East and North Africa. Iran's GDP in 2016 reached 412.2 billion US dollars. Iran's economy has a hydrocarbon sector, an agricultural

\footnotetext{
${ }^{24}$ Nosratollah Nafar, Efficiency and Productivity in Iranian Manufacturing Industries (Stockholm, Kompendiet, 1997),212

${ }^{25} J o a n n a$ De Groot Religion, Culture and Politics in Iran: From the Qajars to Khomeini (London: I.B. Tauris Publisher, 2007),22
} 
sector, services and a presence in the manufacturing and financial services sector. Iran ranks second in the Liquid Natural Gas reserves and fourth in crude oil reserves, Iran has $10 \%$ of the world's oil reserves. Iran also produces 4 billion permil in one day more than half of it is exported, while the rest is consumed for local purposes. The sale of oil is reserved for 152 billion dollars, $80 \%$ of foreign currency and $60 \%$ is used for the country's general budget. ${ }^{26}$

\section{History of the American Embargo}

The United States began an embargo on Iran in 1979. In 1995 United States President, Bill Clinton, forbid all US companies investing in crude oil, Iranian gas. This was also done by the congress and not only that, previously the United States also bombed Iran's offshore oil refineries. In 1996 the United States Congress issued a Penal Code on Iran and Libya. In 2008 the United States banned US banks from becoming intermediaries for the transfer of Iran's international financial traffic. The United States also threatened foreign companies or groups that helped develop Iran's oil sector and froze foreign capital in relations with the Central Bank of Iran. In 2013 the United States government began implementing new penalties on Iran. The signing of the nuclear agreement was signed in 2015 which has made some economic sanctions lifted from Iran with compensation of the Iranian Nuclear Project can be controlled.

\section{Effects of the United States Resignation from the Nuclear Agreement}

On May 8, 2018 United States President, Donald Trump, announced the withdrawal of the United States from the nuclear agreement that had been signed with the European Union known as the $1+5$ agreement. The United States Treasury Secretary said that he would re-impose punishment on Iran in the next 90 to 180 days. ${ }^{27}$ In accordance with the explanation of the United States finance department, he will start his efforts to limit Iran's oil exports after 180 days. During this grace period the United States of America will hold deliberations with

\footnotetext{
${ }^{26}$ M.Hasyim Pesaran, World Economic Prospects and the Iranian Industry (Indianapolis, Indiana State University, 2016), 116

${ }^{27}$ Hamdani Bustam The Politic of Oil and Revolution in Iran (London: Palgrave, 2005), 226
} 
other countries. The United States is working hard to reduce the countries that consume Iranian oil. After 90 days the decision passed, the United States government banned other countries from selling US dollars to Iran and buying minerals and gold and other valuable objects from Iran. Other countries are also banned from buying raw aluminum and Iranian stock investments and any agreements made with the Iranian automotive industry. All forms of airlines such as Boing and Airbus are prohibited from conducting transactions and any relations with Iran starting on August 6. The import of prayer mats and foodstuffs from Iran was banned. ${ }^{28}$ After 180 days of port and ships and shipbuilding, Iran will be given the same sanctions. Not only that, all transactions carried out with the Central Bank of Iran are prohibited, including insurance services. But not all countries comply with this United States decision. It therefore loses its effectiveness because it has a negative impact on Western European companies. The decision to re-impose sanctions against Iran was opposed by several European Union countries and made French economy minister Bruno Lomer on May 9 declared that the United States' decision could not be accepted as a global economic police. Based on the decisions of the big countries (G7) which entered into trade agreements with Iran reject the decision, such as China. China has a value of trade with Iran as much as 20.4 billion Euros, European Union 19.9 billion euros, India 9.5 billion euros, Turkey as much as 9.1 billion euros, South Korea, 9 billion euros, Japan 3.6 billion euros, Switzerland 2.1 billion euros, Russia 1.9 billion euros, Singapore, 1.3 billion euros. The amount of trade between the European Union and Iran increased to 13.7 billion euros and in 2016 increased to 19.9 billion euros in 2017. In addition, the European Union also has other benefits to Iran and other developing countries in the exchange of investment, development of oil and gas fields Iran, exporting heavy equipment and transportation to Iran, such as planes for civil aviation. Total company from France has signed an agreement with a value of 5 billion US Dollars with Iran in a nuclear agreement. Likewise with the British company Petrolium which has

\footnotetext{
${ }^{28}$ Massoud Karshenas Oil and State Industrialization in Iran (London: Bats Press, 1990), 181
} 
cooperated with Iran's national oil company to drill in the Iranian Rum Gas field. Two airlines, like Boing and Airbus, have also signed contracts to deliver 100 aircraft and the second 80 commercial aircraft. This was done after the signing of the nuclear agreement in 2015. These companies will suffer losses by the United States unilaterally withdrawing from the nuclear agreement, the aircraft parts are also from the United States itself.

The soaring oil price is the result of US sanctions against Iran which has imposed losses on commodity exporting countries to Iranian territory. With the rise in oil prices Iran will play a long-standing politics of cheap oil sales. Developing countries will be very interested in the very cheap oil prices. Oil is sold at 5 to 10 dollars cheaper than world market prices. This made China and India apply for a dispensation in purchasing Iranian oil as well as these two countries demanded that economic sanctions against Iran be lifted especially in the oil and gas sector. Turkey is also a country of pure oil importers from Iran. American sanctions against Iran will have a negative impact on the Iranian economy, especially on the Iranian Riyal exchange rate and its effect on inflation. However, its influence will be limited if the European Union does not impose sanctions on Iran. ${ }^{29}$

\section{Iran's Strategic Step in Economic Development}

The Iranian revolution does not yet have a clear economic theory and concept, it will still have a direction to Islam that is mixed with national direction. Then develop in line with the times and conditions of the revolution. Abu Hasan Bani Sadr is a professor of economics and the main advisor to the government of the Iranian Revolution. He was the first to lay out the planning and outline of the direction of Islamic economics in theory which synergizes with Wilayah al-Faqih. Bani Sadhr declared, that reform alone is not enough, but must make a comprehensive change towards economic, political, social, cultural and

\footnotetext{
${ }^{29}$ Keith Crane, RollieLal Iran's Political, Demographic, and Economic Vulnerabilities (Santa Monica:Rand Cooporation, 2008), 38
} 
ideological improvement, this means that progress is impossible to achieve with economic dependence. Therefore, dependence on foreign countries must be stopped, abolishing the existing banking system and establishing a different and in accordance with Islamic sharia. The Iranian currency must be released from its association with the US Dollar, re-combining petrolium with the Iranian economy. It is inevitable that there will be a break in current economic relations with outsiders when changes in the structure of the exporter, distribution in various branches of the economy take place.

Bani Sadhr in his theory said that Islam does not see money as basic capital, what is seen as basic capital is work and activity, because ijtihad is what creates a new invention, it is not wrong if the findings of other parties are used for progress. After the Banu Sadr descended from the leadership of the Islamic Republic of Iran, due to his tendency towards the liberal system. This was done to support his economic theory to realize economic freedom. The economic theory of Bani Sadr has been modified by Ayatullah Bahasyti, which contains seven points $^{30}$ :

\section{Fight poverty}

2. Providing basic needs for each person based on the work he has done

3. Provide opportunities for the development of moral and material abilities of each person,

4. Not wasteful in spending wealth,

5. Maintaining human freedom in the face of economic factors

6. Strengthening domestic economic freedom by developing science and industry,

7. Affirming and enforcing economic justice

The Syariah school of Isna Asyriyah has a distinction with other schools, but it does not show much difference in the economic field. What stands out is only the management of zakat, waqf, disaster management and usury, all of which are

${ }^{30}$ Ibid., 40 
still in the cloak and scope of the mullahs. This treasure aims to provide special assistance that does not yet have a standard procedure and has not yet obtained clear information. ${ }^{31}$ The Revolutionary and Religious Institutions play a role in providing cultural direction and social growth by providing assistance to the poor, victims of the war by providing annual assistance as much as $100,000,000$ Riyals to the foundation and also to reduce the amount of unemployment.

The Iraq-Iran War has provided a change in the Iranian economy, a war that has made the Iranian government severely halt self-sufficiency in various fields. The growth of thought in various ways has proven the truth brought by Islam. Infrastructure development in various dimensions has been able to realize independence in various ways, including in the economic field. Economic development in Iran combines economic revival and social justice. Growth and the nine are not spared from political reform, because political reform is a locomotive to improve the economy, both domestic and foreign politics. Such as avoiding tension, fighting corruption, creating a peaceful atmosphere, adjusting laws related to economic development. With the presence of energy, investment, production, exports and imports as well as other economic activities can be done well. $^{32}$

Privatization is carried out in the fields of strategic industries, such as communication, railroad, tobacco, currency strengthening and privatization of 2,400 institutions. The Higher Institute (Majlis A'la) of the economy issued new rules for investment and free trade territory as one of the solutions of the United States embargo. Continuous changes to the rules can cause investors to worry. Moreover, on the Qeshm island there are 705 industrial projects, 599 service projects and 470 trade projects. Foreign investment in the region amounts to 5,500 billion Iranians and 300 billion foreign investment dollars. The construction

\footnotetext{
${ }^{31}$ Sohrab Chaman Ara Constitution, the way to rescue Iran in light of summary of history (Persian)(Esfahan, Ahmadi Press, 2016),167

${ }^{32}$ Qosroe Chaqueri Firqah-'i jumhūrī inqilābī İrān (gurūh-i nukhustn̄-i Duktur Arānī) va firqah-'i inqilāb-i İrān(Teheran, Pādzahr, 1996), 81
} 
of an international port will continue on this island which will increase investment by 1.5 billion dollars.

In politics there are no permanent-friend or permanent-enemies, just permanent interests. Although the local market has been closed to tertiary necessity, consumer goods are open to basic and strategic needs. The Iranian government is carrying out large transactions, as a supporter of the transit strategy to increase the stretch of the economy which is in the grip of the US embargo. Non-government institutions can also take advantage of government funds in economic development. Iran is trying to develop the economy by building a railroad linking the cities of Sarakhs and Tajan to perfect the old silk route. Iran has also thought about building a channel connecting the Gulf with the Qazwin Sea. The Iranian people really want Iran to be a transit point between East and West as recognized by transportation company experts from Iran, India, Russia, that Iran is technically feasible to be made a Transito region. Goods from India can arrive easily and quickly to Russia, from Mumbai to the Port of Abas in southern Iran. The train will take the goods to the Qazwin Sea, then the goods will be taken to the Astrakhan port in Russia which only takes 15 days $^{33}$. Khazakastan has stated that it will join this trade route. this of course will revive the old trade route that will restore Iran's economy to normal. Trade transactions between Iran and other countries have also increased, such as trade agreements signed with Moscow, South Korea, Japan as the result of hard efforts made by Iran in the face of US pressure in the scientific, technical, and military fields. This is done to preserve natural resources, governance and its presence in the political circle of the Middle East and the world. 500 Iranian experts have prepared a strategic plan until 2022 in realizing the country's national benefit. Iran uses oil to improve its foreign policy, which is always under pressure, so oil and gas can be used as a weapon to face an economic embargo. Oil and gas has been successfully utilized by signing agreements with Russia and China. This allows Iran to remain under pressure from the United States. Iran has also succeeded in establishing

${ }^{33}$ Sohrab ChamanAralbid.76 
agreements with Syria, Lebanon, Turkey, India and even managed to reduce tensions with Pakistan and Armenia. Not only that, Iran's oil weapons have also received support from the Arab community.

Iran has a strong economic foundation because it has the freedom to determine the direction of its economy, military power, abundant natural resources, considerable human resources. Iran's experience during the war in dealing with economic problems and asset management.

Fundamental reforms have been made by Ahmadi Nejat during his time as president. He changed the concept of banking in management, the bank is a service for investors and customers is not a tool for profit seekers or as an intermediary or broker. The second step taken by Ahmadi Najat is to release $50 \%$ of the government's shares in the company in the provinces for the benefit of the people who want to play a role in the company. The private sector is given relief in installment of the share payment for 10 years. The Iranian government is trying to break away from the capitalist and socialist patterns, so that it can become a model of the Islamic economy in the future as a result of long experience in managing an economy based on Islamic sharia. With so capital is no longer circulating fully in the hands of private companies, traders can no longer raise prices at their own will. Iran paved the way to join the world trade organization. The third step is to increase state treasury reserves by increasing investment by providing facilities and adopting the opinions of various parties. The development of nuclear power is done for the purposes of science, energy that supports the industry with low production costs. The economic embargo imposed on Iran is not only felt by Iran, but other parties will also suffer significant losses. Ahmadi Nejat has made reforms in the field of management of government agencies, oversight of the president so that the government can get out of the influence of parties and groups. There was a merger of management 
planning, supervision and executive tools that ended with decentralized economic management ${ }^{34}$.

Ahmadi Nejat also conducts effective eradication of corruption in various sectors, he controls financial management strictly. This is the right media to overcome investment and improve the economy and carry out the mandate of the people who raised it. The Development Jihad Institute has been transformed into the Ministry of Development Jihad, later combined with the Ministry of Agriculture Jihad. Iran's economic journey is aligned with cultural growth, material based on Islamic faith. Harmony will create glory in material and spiritual development. Iran has occupied the first position in the Middle East with a plan of 20 years until 2025. Development must be in accordance with the demands of culture, geography and history. Development must be based on moral foundations, Islamic, national and Revolutionary values that are in line with the development of science. Human resources and balance are one pillar of development. Development must lead to public safety, prosperity, food security, social security, equal opportunities in the distribution and maintenance of family structures, poverty alleviation, corruption, and discrimination that cares about the environment.

Planning based on religious leadership, social justice, freedom of opinion, maintaining respect, human rights, social balance and justice.

\section{Conclusion}

The Iranian Revolution did not run smoothly, but was full of challenges, especially in the economic field which had yet to have clear and standard concepts and plans. Renewal for the sake of renewal is carried out, in the field of economic politics, investment laws to support the development of industry and economic independence. The involvement of various parties has produced a positive impact on the Iranian economy. With the existing government system, it

\footnotetext{
${ }^{34}$ Markaz al-Quds li Dirasah Siyasah Al-Islam Daulah wa Muwatinah Nahwu Khitab Islami Dimuqrati Madani(Amman, Quds Center, 2018),85
} 
will be difficult for a group or party to control policy in Iran. This is due to the involvement of all parties, including the mullahs, parliament, ministries, the government benefit verification assembly, law keepers and others. So that big projects can run well. Iran's economic openness in the global world also has a positive impact on Iran which is continuously embargoed by the United States. Embergo is a whip for Iran to keep going, so that Iran is able to build a strong economy, with the presence of the Carpet, automotive, heavy equipment, excavators / tractors, food industry, petrochemical and the most important sector is the oil and gas sector. Iran's GDP in the oil and gas sector in 2011 reached 824 million dollars. The biggest problem faced by Iran is the embargo, but it did not make this Islamic state paralyzed and even vice versa.

\section{References}

Ahmad Saif Iqtishad Siyasi Khudamani Jaledom ,Teheran:H\&S, 2011.

Ahmad Saif, Iqtishad Siyasi Iran Mu'ashir, Teheran: H\&S, 2018.

Amuzeger, Jahangir Iran,s Economic Under the Islamic Republic, London: I.B Tauris, 2016.

Behzad Yaghmaian Social Change in Iran: An Eyewitness Account of Dissent, Defiance, and New Movements for Rights , New York: State Univrsity of New York, 2002.

Fatimah Shamadi, Tayarat Siyasah Fi Iran, Wadi Nabat: Markaz Dirasat al-Arabia, 2012.

Fawaz bin Hamdi Fawaz Hukuk wa Tashilat li Istitsmar fi Iran, Qatar: Arabia Li Dirasat, 2016.

Ghorbani, Mansour The Economic Geology of Iran, London: Springer 2013.

Hamdani Bustam The Politic of Oil and Revolution in Iran, London: Palgrave, 2005.

Harold, Scott Waren and Nader, Alireza China and Iran: Economic, Political, and Military Relations, California: Rand Corporation, 2012.

Hasan Hakimian, The Economic of Iran, Dilemmas of an Islamic State, London: IB Tauris Publisher, 2010.

Hooshang Amirahmadi, Revolution and Economic Transition: The Iranian Experience, New York: State University of New York Press, 1990.

Ibrahim Gharaybah at-Tsaurah Islamiyah wa Iqtishadiyah, Shira' an-Nakhb Haula Istiqlal Haula Istqlal al-Iqtishadiyah al-Irani, Jeddah:Syubr, 2013. 
Ibrahim Gharaybah at-Tsaurah Islamiyah wa Iqtishadiyah, Shira' an-Nakhb Haula Istiqlal Haula Istqlal al-Iqtishadiyah al-Irani, Jeddah:Syubr, 2013.

Ibrahim Gharaybah at-Tsaurah Islamiyah wa Iqtishadiyah, Shira' an-Nakhb Haula Istiqlal Haula Istqlal al-Iqtishadiyah al-Irani, Jeddah:Syubr, 2013.

Jawad Hasan, "Problem Invest in Iran,” Middle East Economic Journal, 26, no.1 (2014)

Joanna De Groot Religion, Culture and Politics in Iran: From the Qajars to Khomeini , London: I.B. Tauris Publisher, 2007.

Keddie, Niki, Iran: Religion, Politics, and Society, New York: Frank Cass and Company Limited, 2005.

Keith Crane, Rollie Lal Iran's Political, Demographic, and Economic Vulnerabilities, Santa Monica:Rand Cooporation, 2008.

M.Cass Richard Economic Santion and US Diplomacy, London: Palgrave, 2005.

M.Hasyim Pesaran, World Economic Prospects and the Iranian Industry, Indianapolis, Indiana State University, 2016.

Markaz al-Quds li Dirasah Siyasah Al-Islam Daulah wa Muwatinah Nahwu Khitab Islami Dimuqrati Madani, Amman, Quds Center, 2018.

Massoud Karshenas Oil and State Industrialization in Iran, London: Bats Press, 1990.

Nosratollah Nafar, Efficiency and Productivity in Iranian Manufacturing Industries , Stockholm, Kompendiet, 1997.

Parvin Ali Zadeh, Hasan Hakimian, Iran and The Global Economic Petro Populism Islam and Economic Sanction, New York:Routledge, 2014.

Qosroe Chaqueri Firqah-'i jumhūrī inqilābī İrān (gurūh-i nukhust̄̄n-i Duktur Arānī) va firqah-'i inqilāb-i İrān ,Teheran, Pādzahr, 1996.

Sohrab ChamanAraConstitution, the way to rescue Iran in light of summary of history (Persian),Esfahan, Ahmadi Press, 2016. 